\title{
Hubungan derajat merokok dengan kejadian infark miokard di RSUP Prof. Dr. R. D. Kandou Manado
}

\author{
${ }^{1}$ Mutiara B. Wagiu \\ ${ }^{2}$ Janry A. Pangemanan \\ ${ }^{2}$ Agnes L. Panda
}

\author{
${ }^{1}$ Kandidat Skripsi Fakultas Kedokteran Universitas Sam Ratulangi Manado \\ ${ }^{2}$ Bagian Kardiologi Fakultas Kedokteran Unversitas Sam Ratulangi Manado \\ Email: wagiumutiarabetani@yahoo.com
}

\begin{abstract}
Coronary heart disease (CHD) is a disorder of heart function caused by constriction of coronary blood vessels which can manifest as myocardial infarction. Acute myocardial infarction, which is known as "heart attack", is the commonest cause of death in industrial countries. Smoking is one of the various causes of cardiovascular diseases and also the commonest cause of death around the world. According to epidemiologic studies data, there is a simultaneous increase of cigarette consumption and prevalence of myocardial infarction every year. This study was aimed to obtain the correlation between level of smoking and incidence of myocardial infarction at Prof. Dr. R. D Kandou Hospital Manado. This was an observational analytical study with a cross sectional design. Samples were myocardial infarction patients at inpatient wards in Prof. Dr. R. D Kandou Hospital Manado from January 2015 to October 2016 and non-infarction samples with smoking behavior. The Chi-Square test showed that there was a correlation between the level of smoking rated by Brinkman Index and myocardial infarction incidence $(\mathrm{p}=0.001)$. Conclusion: There was a correlation between level of smoking and incidence of myocardial infarction at Prof. Dr. R. D. Kandou Hospital Manado.
\end{abstract}

Keywords: smoking severity, myocardial infarction

\begin{abstract}
Abstrak: Penyakit jantung koroner (PJK) adalah gangguan fungsi jantung akibat otot jantung kekurangan darah karena adanya penyempitan pembuluh darah koroner yang dapat bermanifestasi sebagai infark miokard. Aktivitas merokok termasuk salah satu penyebab dari penyakit kardiovaskular dan merupakan penyebab paling umum kematian di seluruh dunia. Data studi penelitian epidemiologi memperlihatkan adanya peningkatan konsumsi rokok setiap tahunnya yang bersamaan dengan meningkatnya angka kejadian infark miokard. Penelitian ini bertujuan untuk mengetahui hubungan antara derajat berat merokok dengan kejadian infark miokard di RSUP Prof. DR. R. D. Kandou Manado. Jenis penelitian ialah analitik observasional dengan desain potong lintang. Sampel penelitian ialah pasien penderita infark miokard di Ruang Rawat Inap RSUP Prof. DR. R. D. Kandou Manado mulai dari bulan Januari 2015-Oktober 2016 serta sampel non infark dengan kebiasaan merokok. Hasil uji Chi-Square menunjukkan terdapat hubungan bermakna antara derajat berat merokok, yang dinilai berdasarkan indeks Brinkman, dengan kejadian infark miokard $(\mathrm{p}=0,001)$. Simpulan: Terdapat hubungan bermakna antara derajat merokok dengan kejadian infark miokard di RSUP Prof. Dr. R. D. Kandou Manado.
\end{abstract}

Kata kunci: berat merokok, infark miokard

Penyakit jantung koroner (PJK) adalah gangguan fungsi jantung akibat otot jantung kekurangan darah karena adanya penyempitan pembuluh darah koroner. $^{1}$ 
Manifestasi dari PJK salah satunya ialah infark miokard. Istilah infark miokardium menunjukkan terbentuknya suatu daerah nekrosis di miokardium akibat iskemia lokal. Infark miokard akut (IMA), yang dikenal sebagai "serangan jantung", merupakan penyebab tunggal tersering kematian di negara industri. $^{2}$

Prevalensi PJK di Indonesia tahun 2013 pada usia $\geq 15$ tahun berdasar wawancara terdiagnosis dokter sebesar $0,5 \%$ atau diperkirakan sekitar 883.447 orang dan yang berdasarkan terdiagnosis dokter atau gejala sebesar $1,5 \%$ atau sekitar 2.650.340 orang. ${ }^{1}$ Prevalensi PJK berdasarkan terdiagnosis dokter menempatkan Sulawesi Utara, DKI Jakarta, dan Aceh di urutan kedua terbanyak dengan persentase $0,7 \%$ setelah Sulawesi Tengah di urutan teratas dengan persentase $0,8 \%$.

Aktivitas merokok merupakan salah satu penyebab dari sebagian penyakit kardiovaskular dan merupakan penyebab paling umum kematian di seluruh dunia, walaupun merokok sebenarnya bukan merupakan faktor predisposisi yang tidak dapat diubah. Penyakit kardiovaskuler dikatakan sebagai penyebab kematian utama di negara-negara industri, yaitu sebesar 30\% dari semua kematian karena penyakit jantung yang berkaitan dengan akibat merokok. ${ }^{3}$ Data epidemiologi secara konsisten menunjukkan bahwa risiko terjadi infark miokard meningkat secara progresif dengan jumlah rokok yang dikonsumsi seseorang per harinya. Penelitian melaporkan risiko fatal dan non fatal dari infark miokard kira-kira 2-3 kali lebih tinggi pada perokok daripada bukan perokok, dan risiko sudden cardiac death meningkat 10 kali lipat. ${ }^{4}$ Infark miokard merupakan penyebab kematian utama di United States dan negara berkembang di seluruh dunia. ${ }^{4-6}$

Dari data studi penelitian epidemiologi terlihat adanya peningkatan konsumsi rokok setiap tahunnya yang bersamaan dengan meningkatnya angka kejadian infark miokard. Beberapa komponen tembakau dan asap pembakarannya diketahui dapat mengakibatkan kerusakan dinding pembuluh darah yang dapat berujung pada terjadinya infark miokard.

Di Indonesia sendiri, khususnya di Sulawesi Utara, penelitian mengenai kaitan perilaku merokok dengan kejadian infark miokard masih belum banyak dilakukan. Penelitian ini bertujuan untuk mengetahui hubungan antara derajat berat merokok dengan kejadian infark miokard di RSUP Prof. Dr. R. D. Kandou Manado.

\section{METODE PENELITIAN}

Jenis penelitian ini ialah analitik observasional dengan desain potong lintang menggunakan kuesioner. Penelitian dilaksanakan di Ruang Rawat Inap Rumah Sakit Umum Pusat (RSUP) Prof. Dr. R. D. Kandou Manado pada bulan SeptemberNovember 2016. Populasi penelitian ini ialah pasien penderita infark miokard di Ruang Rawat Inap RSUP Prof. DR. R. D. Kandou Manado, mulai dari bulan Januari 2015-Oktober 2016, dan responden noninfark yang memiliki kebiasaan merokok yang dijangkau dengan teknik purposive sampling. Kriteria inklusi penelitian ini, yaitu responden infark miokard dan noninfark miokard, mempunyai perilaku kebiasaan merokok, berusia $>18$ tahun, dan bersedia menjadi responden. Kriteria eksklusi yaitu pasien infark miokard dengan penyerta hipertensi dan diabetes melitus, rokok yang dikonsumsi ialah rokok elektrik, dan menolak menjadi responden.

Variabel yang digunakan yaitu derajat merokok menggunakan indeks Brinkman sebagai variabel bebas, dan kejadian infark miokard sebagai variabel terikat. Instrumen penelitian meliputi data rekam medik dan kuesioner.

Data diolah berdasarkan variabel penelitian dengan menggunakan uji statistik SPSS versi 20 yang dianalisis menggunakan uji Chi Square dan disajikan dalam bentuk tabel, grafik, dan persentase.

\section{HASIL PENELITIAN}

Dalam periode Januari 2015 - Oktober 2016 didapatkan total 62 responden yang terbagi atas 31 responden yang pernah 
dirawat di RSUP Prof. Dr. R. D. Kandou Manado dengan diagnosis infark miokard dan 31 responden non infark miokard yang memiliki kebiasaan merokok. Tabel 1 menunjukkan bahwa dari total 62 responden penelitian, laki-laki berjumlah 54 orang $(87,1 \%)$ dan perempuan berjumlah 8 orang $(12,9 \%)$ dengan jumlah pada kriteria infark dan non infark sama yakni 37 laki-laki dan 4 perempuan pada masing-masing kategori.

Tabel 1. Distribusi berdasarkan jenis kelamin

\begin{tabular}{ccccc}
\hline $\begin{array}{c}\text { Jenis } \\
\text { kelamin }\end{array}$ & Infark & $\begin{array}{c}\text { Non } \\
\text { infark }\end{array}$ & Jumlah & \% \\
\hline $\mathrm{L}$ & 27 & 27 & 54 & 87,1 \\
$\mathrm{P}$ & 4 & 4 & 8 & 12,9 \\
Total & 31 & 31 & 62 & 100 \\
\hline
\end{tabular}

Tabel 2 menunjukkan bahwa responden terbanyak berusia 50-59 tahun sebanyak 19 orang $(30,6 \%)$, diikuti usia 40 49 tahun sebanyak 13 orang $(21,0 \%)$, usia 60-69 tahun dan usia 30-39 tahun masingmasing sebanyak 9 orang $(14,5 \%)$, usia 20 29 tahun sebanyak 7 orang $(11,3 \%)$, usia 70-79 tahun sebanyak 4 orang $(6,5 \%)$, dan usia $>80$ tahun hanya 1 orang $(1,6 \%)$.

Tabel 2. Distribusi berdasarkan usia

\begin{tabular}{ccccc}
\hline Usia & Infark & $\begin{array}{c}\text { Non } \\
\text { infark }\end{array}$ & Jumlah & \% \\
\hline $20-29$ & 1 & 6 & 7 & 11,3 \\
$30-39$ & 2 & 7 & 9 & 14,5 \\
$40-49$ & 5 & 8 & 13 & 21,0 \\
$50-59$ & 12 & 7 & 19 & 30,6 \\
$60-69$ & 6 & 3 & 9 & 14,5 \\
$70-79$ & 4 & 0 & 4 & 6,5 \\
$\geq 80$ & 1 & 0 & 1 & 1,6 \\
Total & 31 & 31 & 62 & 100 \\
\hline
\end{tabular}

Tabel 3 menunjukkan 2 responden $(3,2 \%)$ mulai merokok sebelum usia 10 tahun, 21 responden $(33,9 \%)$ mulai merokok pada rentang usia 11-15 tahun, 29 responden $(46,8 \%)$ pada rentang usia $16-20$ tahun, dan 10 responden $(16,1 \%)$ mulai merokok setelah usia 20 tahun.

Tabel 4 menunjukkan bahwa dari total 62 responden, 56 orang $(90,3 \%)$ mengonsumsi jenis rokok kretek sedangkan
4 orang $(9,7 \%)$ sisanya mengonsumsi jenis rokok putih.

Tabel 3. Distribusi berdasarkan usia awal merokok

\begin{tabular}{ccccc}
\hline $\begin{array}{c}\text { Usia } \\
\text { awal }\end{array}$ & Infark & $\begin{array}{c}\text { Non } \\
\text { Infark }\end{array}$ & Jumlah & \% \\
\hline$\leq 10$ & 1 & 1 & 2 & 3,2 \\
$11-15$ & 10 & 11 & 21 & 33,9 \\
$16-20$ & 16 & 13 & 29 & 46,8 \\
$>20$ & 4 & 6 & 10 & 16,1 \\
Total & 31 & 31 & 62 & 100 \\
\hline
\end{tabular}

Tabel 4. Distribusi berdasarkan jenis rokok

\begin{tabular}{ccccc}
\hline $\begin{array}{c}\text { Jenis } \\
\text { rokok }\end{array}$ & Infark & $\begin{array}{c}\text { Non } \\
\text { infark }\end{array}$ & Jumlah & \% \\
\hline Kretek & 27 & 29 & 56 & 90,3 \\
Putih & 4 & 2 & 6 & 9,7 \\
Total & 31 & 31 & 62 & 100 \\
\hline
\end{tabular}

Tabel 5 menunjukkan bahwa mayoritas responden baik infark dan non-infark telah memiliki kebiasaan merokok $>20$ tahun, yakni 29 responden infark $(46,8 \%)$ dan 15 responden non infark $(24,2 \%)$. Responden infark dengan kebiasaan merokok antara 11-20 tahun sejumlah 1 orang $(1,6 \%)$ dan responden non-infark dengan durasi yang sama sejumlah 9 orang $(14,5 \%)$ sedangkan untuk responden yang memiliki riwayat merokok $<10$ tahun sejumlah 7 responden non-infark $(11,3 \%)$ dan 1 responden dengan infark miokard $(1,6 \%)$.

Tabel 5. Distribusi berdasarkan lama merokok

\begin{tabular}{ccccc}
\hline Lama & Infark & $\begin{array}{c}\text { Non } \\
\text { Infark }\end{array}$ & Jumlah & $\%$ \\
\hline$\leq 10$ & 1 & 7 & 8 & 12,9 \\
$11-20$ & 1 & 9 & 10 & 16,1 \\
$>20$ & 29 & 15 & 44 & 71,0 \\
Total & 31 & 31 & 62 & 100 \\
\hline
\end{tabular}

Tabel 6 menunjukkan bahwa responden dengan infark miokard paling banyak mengonsumsi rokok $>20$ batang per hari dengan jumlah 17 orang $(27,4 \%)$, sedangkan responden non-infark yang mengonsumsi jumlah yang sama hanya 5 orang $(8,1 \%)$. Mayoritas responden sejumlah 23 orang, termasuk dalam kategori yang mengonsumsi 11-20 batang 
per harinya, yang terbagi atas 8 responden dengan infark miokard $(12,9 \%)$ dan 15 responden non-infark $(24,2 \%)$.

Tabel 7 menunjukkan responden yang masuk kategori perokok berat paling banyak dengan infark miokard, berjumlah 18 orang $(72,0 \%)$, dan 7 orang $(28,0 \%)$ sisanya merupakan responden non-infark. Untuk kategori perokok sedang, terdapat 11 responden dengan infark $(52,4 \%)$, dan 10 responden tanpa infark $(47,6 \%)$. Mayoritas responden non-infark dikategorikan sebagai perokok ringan dengan jumlah 14 orang $(87,5 \%)$, dan hanya 2 orang $(12,5 \%)$ yang merupakan responden infark miokard. Hasil analisis Chi-Square diperoleh nilai $\mathrm{p}=$ $0,001(\mathrm{p}<0,05)$ yang menunjukkan terdapat hubungan bermakna antara derajat berat merokok dengan kejadian infark miokard di RSUP Prof. Dr. R. D. Kandou Manado.

Tabel 6. Distribusi berdasarkan jumlah rokok

\begin{tabular}{ccccc}
\hline Jumlah rokok/hari & Infark & Non infark & Jumlah & \% \\
\hline $1-10$ & 6 & 11 & 17 & 27,4 \\
$11-20$ & 8 & 15 & 23 & 37,1 \\
$>20$ & 17 & 5 & 22 & 35,5 \\
Total & 31 & 31 & 62 & 100 \\
\hline
\end{tabular}

Tabel 7. Hubungan derajat merokok dengan kejadian infark miokard

\begin{tabular}{ccccc}
$\begin{array}{c}\text { Indeks } \\
\text { Brinkman }\end{array}$ & Infark & Non-infark & $\begin{array}{c}\text { Jumlah } \\
(\%)\end{array}$ & $\boldsymbol{P}$ \\
Ringan & $2(12,5 \%)$ & $14(87,5 \%)$ & $16(100 \%)$ & \\
Sedang & $11(52,4 \%)$ & $10(47,6 \%)$ & $21(100 \%)$ & 0,001 \\
Berat & $18(72,0 \%)$ & $7(28,0 \%)$ & $25(100 \%)$ & \\
Total & 31 & 31 & 62 & \\
\hline
\end{tabular}

\section{BAHASAN}

Dari 62 responden yang ditemukan, sebanyak 54 responden $(87,1 \%)$ berjenis kelamin laki-laki, sedangkan 8 responden $(12,9 \%)$ berjenis kelamin perempuan. Kebiasaan merokok sangat dipengaruhi oleh konteks historis masyarakat dan norma budaya, dan dalam masyarakat umumnya jumlah perokok laki-laki lebih banyak dari perokok perempuan. Dari kebiasaan merokok masyarakat jelas menunjukkan sebagian alasan dari jumlah infark miokard pada perempuan yang lebih muda lebih sedikit dibandingkan dengan laki-laki. Jumlah penderita perempuan yang lebih sedikit ini juga didukung dengan teori yang menyatakan bahwa perempuan, khususnya usia muda, secara relatif terhindar dari penyakit jantung koroner. Alasannya dikaitkan dengan peran protektif hormon estrogen, yang meskipun mekanisme jelasnya belum dipahami sepenuhnya, namun efek langsung estrogen pada sistem vaskular meliputi peningkatan pelepasan nitrik oksida yang menyebabkan vasodilatasi, pengaturan fungsi prostaglandin, dan penghambatan proliferasi otot polos. ${ }^{7,8}$ Anand et al. (2008) dalam penelitiannya menyimpulkan bahwa wanita mengalami infark miokard akut pertamanya 9 tahun setelah pria. Perbedaan usia tersebut dijelaskan oleh level faktor risiko yang lebih tinggi di usia muda pria dibanding wanita. ${ }^{9}$ Yang et al. (2012) juga dalam studi mendapatkan usia pasien yang lebih tua pada wanita, yang menyiratkan arteri koroner normal dan pola hidup sehat lebih banyak pada wanita dibandingkan pria dengan usia yang sama. ${ }^{10}$

Berdasarkan umur, penderita infark miokard paling banyak berada pada rentang usia 50-59 tahun. Berdasarkan teori, kerentanan terhadap aterosklerotik koroner meningkat seiring bertambahnya usia, karena terjadi perubahan anatomik dan fisiologik pada jantung dan pembuluh 
darah. Semakin tua usia maka fungsi kerja jantung cenderung berkurang, dinding pembuluh darah menjadi kaku dan keras, yang dapat berakibat penumpukan lemak/plak lebih mudah terjadi dan menghalangi aliran darah yang berisiko memicu proses aterosklerosis dan dapat berujung pada terjadinya PJK. ${ }^{11}$ Dikatakan bahwa jarang timbul penyakit yang serius sebelum usia 40 tahun, namun insidensi MI meningkat 5 kali lipat pada usia 40 hingga 60 tahun. $^{12}$ Pada studi populasi BMJ mengenai merokok dan infark miokard pada wanita dan pria dikatakan bahwa perbedaan risiko lebih tinggi pada pria umur 65 tahun dan pada wanita diatas 65 tahun. ${ }^{13}$ Penelitian oleh Koek et al (2007) mendapatkan data yang menunjukkan insidensi infark miokard akut pertama di Netherlands lebih tinggi pada laki-laki dibandingkan pada perempuan dari semua kelompok umur, tapi rasio antara pria dan wanita berkurang setelah umur 50-59 tahun. $^{14}$

Pada tabel 3, usia awal merokok pasien infark dan non infark terbanyak, dengan jumlah 29 orang $(46,8 \%)$, berada pada rentang umur 16-20 tahun, yakni sebanyak 16 sampel infark dan 13 sampel non infark, dengan usia awal merokok rata-rata 17 tahun untuk kelompok infark, dan 18 tahun untuk kelompok non infark. Nasution (2007) dalam penelitiannya menyatakan bahwa perokok pada umumnya mulai merokok pada usia remaja diatas 13 tahun. ${ }^{15}$ Orang yang merokok pertama kali pada usia 16-18 tahun dikatakan akan langsung menjadi regular smoker, yaitu orang yang merokok minimal 1 batang/hari, bukan lagi merokok sebagai upaya coba-coba. ${ }^{16}$

Jenis rokok yang paling banyak dikonsumsi sampel penelitian adalah rokok kretek yakni berjumlah 56 orang $(90,3 \%)$, sedangkan rokok putih hanya sejumlah 6 orang $(9,7 \%)$. Meskipun dalam jumlah perokok kretek lebih banyak, namun secara statistik rokok putih lebih banyak menyebabkan infark miokard, yakni 4 orang $(66,7 \%)$ dari total 6 orang perokok putih. Hal ini bertentangan dengan penelitian Afriyanti (2015) dimana didapatkan jenis rokok kretek mempunyai risiko 6,5 kali lebih besar dibandingkan dengan jenis rokok putih dalam risiko PJK di Poliklinik Pusat Jantung - Pembuluh Darah dan Otak Terpadu RSUP Prof. DR. R. D. Kandou Manado, yang dikaitkan dengan kandungan nikotin dan tar yang lebih tinggi pada rokok kretek dibandingkan rokok putih. ${ }^{17}$ Fitriani dkk (2009) dalam hasil penelitiannya juga menyatakan bahwa risiko PJK 3 kali lebih lebih besar secara signifikan pada orang yang merokok kretek. ${ }^{16}$ Perbedaan hasil ini mungkin disebabkan adanya faktor risiko lain dari perokok putih, misalnya riwayat keluarga, obesitas, dan dyslipidemia. Meskipun dalam CDC 2010 menyatakan bahwa dalam ulasan komprehensif tentang penggunaan low-tar cigarettes tidak menunjukkan pengurangan risiko yang berarti jika dibandingkan dengan merokok pipa dan cerutu. $^{18}$ Sedangkan dalam penelitian Domma dkk tahun 2015 dikatakan tidak ada perbedaan risiko yang dapat dibuktikan antara berbagai jenis tembakau (pipa, cerutu, atau rokok polos dan disaring). ${ }^{8}$

Dari data lama merokok didapatkan 29 $(46,8 \%)$ penderita infark miokard dan 15 $(24,2 \%)$ yang bukan merupakan penderita, telah merokok lebih dari 20 tahun. Umur dikatakan kolinear dengan durasi merokok karena, kedua variabel tumbuh bersamasama berdasarkan saat awal seseorang mulai merokok. Selain itu, sebagian perokok mulai merokok selama masa remaja, yang mempromosikan kolinearitas tersebut. Analisis data dalam studi dari American Cancer Society menunjukkan peningkatan yang stabil dalam angka kematian PJK dengan meningkatnya durasi merokok untuk orang sebelum usia 70 tahun. $^{18}$ Dayu $^{19}$ dalam penelitiannya menemukan adanya hubungan antara riwayat lama merokok dengan angka kejadian PJK di RSUD DR. H. Abdul Moeloek, yang didukung oleh teori Bustan yaitu semakin muda usia seseorang merokok, maka semakin tinggi risiko terkena pengaruhnya, salah satunya yakni 
aterosklerosis, karena lamanya merokok dihubungkan dengan lamanya terpapar dengan zat-zat kimia yang terkandung dalam rokok. Studi yang dilakukan Elkhader et al. ${ }^{20}$ mendukung teori yang menyatakan peningkatan durasi perilaku merokok meningkatkan kejadian infark miokard. Doll et al. melaporkan bahwa korelasi positif dapat ditemukan sejauh durasi merokok dikaitkan dengan riwayat merokok 10-20 tahun. ${ }^{20}$

Berdasarkan jumlah batang rokok per hari dari total kasus infark miokard yang ditemukan, jumlah terbanyak pada kategori lebih dari 20 batang, sebanyak 17 orang $(27,4 \%)$ sedangkan, sebagian besar sampel non infark mengonsumsi 11-20 batang per hari dengan jumlah 15 orang $(24,2 \%)$. Kalalo $^{21}$ dalam penelitiannya menyatakan bahwa perokok berat ( $>20$ batang sehari) memiliki kemungkinan lebih besar terkena serangan infark miokard akut daripada perokok sedang (11-20 batang). Dikatakan bahwa merokok dipengaruhi risiko signifikan in a dose-dependent manner, yaitu risiko meningkat 2-3\% untuk setiap gram tembakau yang dihisap setiap hari. ${ }^{8}$ Laporan Surgeon General (USDHHS 2004, 2010) menunjukkan peningkatan risiko PJK di semua tingkat merokok, dan risiko yang lebih besar terbukti bahkan pada orang yang merokok kurang dari 5 batang rokok per hari bila dibandingkan dengan orang yang tidak merokok. Bukti yang telah dibahas dalam laporan Surgeon General 2010 menunjukkan peningkatan risiko PJK dengan banyak rokok yang dihisap per hari hanya sampai sekitar 25 rokok; dari titik itu, risiko yang dikenakan oleh kenaikan lebih lanjut dalam konsumsi rokok lebih kecil peningkatannya secara bertahap. Sebaliknya, data dari lima kohort kontemporer (Thun et al. 2013) menunjukkan kecenderungan secara signifikan kenaikan peningkatan risiko kematian PJK untuk laki-laki ( $\mathrm{p}<0,0001)$ dan perempuan ( $\mathrm{p}<0,003$ ) mencapai 40 batang rokok per hari, sedangkan Kenfield et al. tahun 2008 menyatakan dalam studi Nurses' Health, tren peningkatan risiko kematian PJK akibat merokok ialah signifikan melampaui
35 batang atau lebih per hari. ${ }^{18,22}$

Dari hasil yang didapatkan, terlihat bahwa sebagian besar sampel dengan infark miokard merupakan perokok berat, yaitu sebanyak 18 orang, sedangkan sampel non infark mayoritas tergolong sebagai perokok ringan, yaitu sebanyak 7 orang. Hasil penelitian ini sesuai dengan teori yang mengatakan bahwa merokok merupakan faktor risiko utama penting yang dapat dimodifikasi, yang diketahui sebagai pemicu terjadinya $\mathrm{PJK}^{8}{ }^{8}$ Hasil ini sejalan dengan hasil penelitian $\operatorname{Nardian}^{23}$ yang menyatakan terdapat hubungan antara derajat berat merokok dengan kejadian infark miokard dan perokok berat, yang juga dinilai berdasarkan Indeks Brinkman, 26 kali lebih besar risikonya terkena infark miokard dibandingkan perokok ringan, dan 11,43 kali lebih besar dibandingkan perokok sedang. CDC 2010 menyatakan bahwa risiko kardiovaskular akibat merokok meningkat dengan jumlah rokok per hari dan durasi merokok. ${ }^{18}$ Hal ini dikaitkan dengan penumpukan zat kimia yang terkandung di dalam rokok akibat paparan dari jumlah rokok dan lamanya merokok yang bervariasi pada setiap orang. Seperti yang dijelaskan dalam teori, efek merokok dan kandungan zat kimia didalamnya antara lain CO menyebabkan karboksihemoglobin, nikotin merangsang produksi adrenalin, berkurangnya kadar HDL, terjadi aterosklerosis, yang dapat berujung pada terjadinya serangan jantung. ${ }^{24}$

\section{SIMPULAN}

Dari hasil penelitian dapat disimpulkan bahwa terdapat hubungan bermakna antara derajat merokok dengan kejadian infark miokard di RSUP. Prof. Dr. R. D. Kandou Manado.

\section{SARAN}

Disarankan sebagai tindak lanjut berupa edukasi tentang dampak kebiasaan merokok terhadap kejadian infark miokard. Pada penelitian selanjutnya diharapkan dilakukan penelitian dengan jumlah sampel yang lebih besar dan rentang waktu 
penelitian yang lebih panjang untuk mendapatkan hasil penelitian yang maksimal, mengendalikan variabel perancu lainnya, serta dilakukan dengan sumber data primer untuk mempermudah pengumpulan data secara lengkap.

\section{DAFTAR PUSTAKA}

1. Balitbang Kemenkes RI. Riset Kesehatan Dasar. 2013 Dec 1 [cited 2016 Aug 29]. Available from: http://www.depkes.go.id/resources/downl oad/general/Hasil\%20Riskesdas\%202013. pdf

2. Kumar V, Cotran RS, Robbins SL. Jantung. In: Hartanto H, Darmaniah N, Wulandari N, editors. Buku Ajar Patologi (7th ed). Jakarta: EGC, 2007; p. 410.

3. Pusat Jantung Nasional Harapan Kita (n.d.). Rokok dan Kesehatan Jantung. Retrieved Aug 29, 2016. Available from http://www.pjnhk.go.id/index.php/pelaya nan/86-rokok-dan-kesehatan-jantungartikel

4. Grines CL, Topol EJ, O’Neill WW, George BS, Kereiakes D, Phillips HR, et al. Effect of cigarette smoking on outcome after thrombolytic therapy for myocardial infarction. 1995 Jan 15 [cited 2016 Aug 29]. Available from: http://circ.ahajournals.org/content/91/2/29 8

5. Bolooki HM, Askari A. Acute myocardial infarction. 2010 Aug [cited 2016 Aug 29]. Available from: http://www.clevelandclinimeded.com/me dicalpubs/diseasemanagement/cardiology /acute-myocardial-infarction/\#top

6. World Health Organization. Heart Disease. Retrieved Aug 29, 2016, from http://www.who.int/tobacco/research/hear $\mathrm{t}$-disease/en/

7. AHA Scientific Statement. Acute myocardial infarction in women: A scientific statement from the American Heart Association. January 252016 [cited 2016 Nov 9]. Available from: http://www.circ.ahajournals.org/content/1 33/9/916

8. Domma AM, Gamal MA. Association between acute myocardial infarction, lipid profile and smoking habit. IOSR J Dent Med Sci. 2015;14:47-51.

9. Anand SS, Islam S, Rosengren A, Franzosi MG, Steyn K, Yusufali AH, et al.. Risk factors for myocardial infarction in women and men: insights from the INTERHEART study, Eur Heart J. 2008: 835-36.

10. Yang HY, Huang JH, Hsu CY, Chen YJ. Gender differences and the trend in the acute myocardial infarction: A 10-year nationwide population-based analysis. The Scientific World Journal. 2012;2012:1-11.

11. University of Maryland Medical Center. Aging changes in the heart and blood vessels. 2015 [cited 9 November 2016]. Available from: http://umm.edu/health/medical/ency/articl es/aging-changes-in-the-heart-and-bloodvessels

12. Price SA, Wilson LM. Gangguan sistem kardiovaskular. In: Hartanto H, Susi N, Wulansari P, Mahanani DA, editors. Patofisiologi Konsep Klinis Prosesproses Penyakit (6th ed). Jakarta: EGC; 2006; p. 579-93.

13. Prescott E, Hippe M, Schnor P, Hein HO, Vestbo J. Smoking and risk of myocardial infarction in women and men: longitudinal population study. BMJ. 1998:316:1043-7.

14. Koek HL, de Bruin A, Gast A, Gevers E, Kardaun IWPF, Retisma JB, et al. Incidence of first acute myocardial infarction in the Netherlands. Netherlands Journal of Medicine. 2007; 65(11):43441.

15. Nasution IK. Perilaku merokok pada remaja [Makalah]. Medan: FK USU; 2007.

16. Umar F. Perilaku merokok dan lingkungan pemukiman pasien rawat jalan penyakit jantung koroner di Makassar [Skripsi]. Makassar: Program Sarjana Kesehatan Masyarakat Unhas; 2009.

17. Afriyanti R. Hubungan antara perilaku merokok dengan kejadian penyakit jantung koroner [Skripsi]. Manado: FK Unsrat; 2015.

18. Centers for Disease Control and Prevention (CDC). 2010. How tobacco smoke cause disease: the biology and behavioral basis for smoking attributable disease. Atlanta (GA): Centers for Disease Control and Prevention (US). 2010:2-7.

19. Dayu, MS. Hubungan Riwayat Lama Merokok Dengan Angka Kejadian Penyakit Jantung Koroner di RSUD DR. H. Abdul Moeloek Provinsi Lampung 
Tahun 2015 [Skripsi]. Lampung: FK Malahayati; 2015.

20. Elkhader BA, Abdulla AA, Omer MA. 2016. Correlation of smoking and myocardial infarction among Sudanese male patients above 40 years old of age. Polish Journal of Radiology. 2016;81(10):137-40.

21. Kalalo GF. Pengaruh gaya hidup merokok terhadap kejadian infark miokard akut (IMA) di RSU Bethesda Tomohon [Skripsi]. Manado: FK Unsrat; 2013.

22. National Center for Chronic Disease Prevention and Health Promotion (US)
Office on Smoking and Health US Department of Health and Human Services. 2014. The health consequences of smoking - 50 years of progress: A report of the surgeon. General Atlanta (GA): Centers for Disease Control and Prevention (US), 2014:423-9.

23. Nardian DF. Hubungan derajat berat merokok dengan kejadian infark miokard [Skripsi]. Surakarta: FK UNS; 2015.

24. Ambrose JA, Barua RS. The pathophysiology of cigarette smoking and cardiovascular disease. J Am Coll Cardiol. 2004;43(10):1731-37. 